\title{
Role of gamification in classroom teaching: Pre-service teachers' view
}

\author{
Rita Wong Mee Mee, Tengku Shahrom Tengku Shahdan, Md Rosli Ismail, Khatipah Abd Ghani, \\ Lim Seong Pek, Wong Yee Von, Adelaide Woo, Yugeshineey Subba Rao \\ Faculty of Education and Social Sciences, Universiti Selangor, Malaysia
}

\begin{tabular}{l}
\hline \hline Article Info \\
\hline Article history: \\
Received Mar 27, 2020 \\
Revised Jul 11, 2020 \\
Accepted Aug 5, 2020
\end{tabular}

Keywords:

Engagement

Game-based learning

Gamification

Motivation

Pre-service teacher

\begin{abstract}
Planning a creative learning environment is not an easy task. Teachers prefer to teach traditionally in chalk-and-talk approach during language teaching. However, this does not fit learners of the 21 st Century as they prefer gamelike activities instead of pen-and-paper lessons. Hence, the introduction of gamification in classroom would result in immediate enthusiasm and curiosity, which leads to the learners' willingness to learn. Gamification prepares learners to be active and take responsibility upon their own learning. Lessons filled with fun games are believed to be more effective in producing a positive outcome as learners are motivated to play more although they do not realise the fact that they are learning subconsciously. This study aimed to explore views of 33 pre-service teachers in using gamification in language teaching during their 16-week internship at local primary schools around Selangor, Malaysia. A quantitative survey research method was used by administering a set of questionnaires at the end of their internship. The data collected was then analysed and presented in the form of tables. The results showed that integrating gamification into language learning improved learners' creative, critical and problem-solving skills. Thus, interesting and engaging activities spark learners' interest in language learning subconsciously.
\end{abstract}

This is an open access article under the CC BY-SA license.

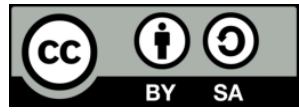

\section{Corresponding Author:}

Rita Wong Mee Mee,

Faculty of Education and Social Sciences,

Universiti Selangor,

Bestari Jaya Campus, Selangor Darul Ehsan, Malaysia.

Email: ritawong@unisel.edu.my

\section{INTRODUCTION}

21 st-century skills refer to the core competencies such as collaboration, digital literacy, critical thinking, and problem-solving that need to be taught to help learners to thrive in today's world. In order for learners to possess these skills, teachers are expected to be able to create inspiring content to attract learners to attain useful knowledge for the future. This study was carried out to suggest the use of game play in the concept of game-based learning in primary schools. Games are able to provide interesting learning activities that incorporate learning values into these lessons and gamification is defined as a concept that evolves with the technology era as it includes new strategies and ways to develop learning [1]. It is a reality that games are able to help learners understand language learning in a better way.

As the world progresses, teachers find creative ways to attract learners into learning in order to produce successful learners that lead the generation to come. In the era of digital technology, teachers should equip themselves with at least the basic skills to utilize a computer in order to design meaningful content for 
learners learning. One of the many ways teachers may use into making lessons fun and interesting is by implementing games into their classroom teaching. Learners have greater interest in lessons that utilise games as part of the learning experience and those games manage to give learners motivation they need when carrying out learning activities during lessons [2].

However, there are many misconceptions and questions raise upon the use of gamification in the educational setting. Some of which Koh, Kin, Wadhwa and Lim [3] suggested are; 1) games take too much time to create; 2) limited resources into creating games; 3) the cost of production is higher; 4) it does not support teaching topics directly; and 5) schools and/or parents are not supportive to the idea. In addition, another challenge in integrating ICT into pedagogical practice directly related to teacher's confidence as well as teachers' competence has resulted in many teachers reluctant in using games in classroom teaching [4].

In contrast, many other studies show that games are highly useful and show a high degree of effectiveness for the teachers' classroom teaching. Teachers agree games use in their classroom shows positive outcomes and suggest several factors into adopting games in teaching lessons [3]. Teachers play an important role to build fun learning opportunities for learners to make meaning and to prepare learners for the future as they leave for the real world. Besides, game-based learning helps weaker learners to catch up with lessons easily with the integration of materials as a form of learning aid. The integration of games as learning materials stimulate learners' interest to learn English language effectively [5].

Hence, this study was conducted to determine pre-service teachers' views in using gamification in their language teaching. Apart from that, this study enabled greater understanding on how fun and interesting lessons could be incorporated. The significance of this study had raised awareness of pre-service teachers to gain control in integrating gamification elements in language teaching.

\section{LITERATURE REVIEW}

Gamification, as a concept, is defined as the techniques used in non-game settings and gamification as serious games, in particular, are not clichéd processes, but rather general procedures aiming at transferring the logic and elements of play into pedagogical practices [6]. Games are where players being thrown into an environment in which they are to solve problems to move forward without knowing the outcomes of their decision [7]. Studies show that game design elements are more difficult to define, owing to the multiple theoretical frameworks that have been produced, each with idiosyncratic classification systems and levels of abstraction [8]. Gamification techniques are commonly used in higher education to increase learners' motivation and engagement in a learning task $[9,10]$.

Gamification can provide a rich learning context to help learners construct higher-level knowledge through ambiguous and challenging trial-and-error opportunities [11]. Through games, learners are able to learn in an exciting, entertaining way while increasing their knowledge and understanding of the subject matter [1]. The integration of game-based learning to the like of math homework where learners gain points and calculate to receive the higher rank among each other is another example of how gamilfication is applied into classroom teaching [12]. In a way, learners are required to achieve points and the players that receive the highest points would automatically win the whole game. This allows learners to compete in a friendly way and be more active to answer questions and eager to learn in order to obtain points to "win" the game. The importance of game knowledge where in most part, instructional designers who know little about game development will, therefore, know little about training, education and instructional design [13].

Many previous studies on gamification have argued that by motivating learners through a reward-based learning method, their learning skills will be enhanced and eventually increase their learning outcomes [14]. The element of progression is a very important element for games. Most of all for the level of engagement and motivation it gives to the player. The main objective is to maintain the player informed on how much progress he or she has in the level. In addition, games give players the necessary information about the goals that were completed and the necessary tasks to complete a level [15]. It also represents the player's journey, which could be part of a series of small challenges embedded into a larger challenge.

Gamification - through the use of stimuli and extrinsic rewards - has a direct influence on extrinsic motivation [16]. Reward-based gamification solely relies on the external provision of rewards to influence learners' behaviour. The behavioural change through reward-based gamification tends to be conditional on the continuous provision of extrinsic rewards, unless the motivation for the behavioural change is internalized [17]. In situations where there is a lack of intrinsic motivation for a certain behavior, and the behaviour does not require a tremendous amount of mental effort; reward-based gamification is expected to be motivationally sufficient. Thus, reward-based gamification is effective for quick, short termed behavioural change that lasts for as long as the rewards are available [18].

In the use of games in gamification education, Yolageldili and Arikan [19] explained that respondents see games as a significant role for classroom teaching and learning. These games are also able to 
provide teachers a variety of benefits for their classroom to achieve the learning outcomes. Moreover, learners not only learn in a fun environment but are able to enhance their creativity and problem solving as they are learning subconsciously. A local study shows that respondents show positive attitude in the use of game-based learning since it assisted in their confidence and the product was easy to use [20]. The respondents, especially teachers, show plans in integrating games in their class teaching in the future.

Even though there have been many past studies showing beneficial and positive responses towards the use of gamification in education, a number of previous studies have been identified stating gamification techniques may not necessarily offer the best option and outcome of learning to the learners [9]. Gamification was found not significantly improve learners' grades as most of them were unfamiliar with the protocol of gamification [21]. In addition, learners' unfamiliarity with the gamification approach has been reported as the main reason for not being able complete tasks [22]. However, it is still debatable how certain gamification techniques can stimulate learners' learning.

\section{RESEARCH METHOD}

This study was carried out to determine the views of pre-service teachers in using gamification to improve primary school learners' language learning ability. Therefore, this study used quantitative survey research method to analyse the effectiveness of gamified language learning activities in language classroom. Quantitative method shows a cause and effect relationship with numerical data and hard facts [23]. The results can be shown in statistics, tables, graphs as well as charts. Quantitative method is a method that uses measurable variables and statistical procedures can be used to analyse the numbered data in instruments [23]. Hence, quantitative method fits this study the most as it aids the study with clear and understandable data.

The study was conducted on 33 pre-service teachers, studying at the education faculty of a local private university in Malaysia. All the 33 pre-service teachers enrolled in Teaching English as a Second Language (TESL) programme during undergraduate training. The participants were in their final semester of the two and a half years programme. During the final semester, the participants were having 16-week internship teaching at various primary schools around Selangor, Malaysia. In this study, the main aims are to analyse pre-service teachers' views on the use of gamification in language teaching and to identify learners' social skills development through gamified language activities. In addition, the participants participated in the survey are voluntary.

Likert Scale was used as a measurement for data collection. The Likert Scale of the questions was categorized to 1 (Totally Disagree), 2 (Disagree), 3 (Neutral), 4 (Agree) and lastly 5 (Totally Agree). There were 22 questions in total for a set of questionnaires divided into three sections. Section A was used to show pre-service teachers' preferences in using games during language teaching. Section B was used to determine barriers while using gamified activities in language teaching and Section $\mathrm{C}$ was used to analyse pre-service teachers' perception on the effectiveness of using gamification in language teaching. Respondents answered the questionnaire individually.

The results were analysed by using Statistical Package for the Social Science (SPSS). In this study, SPSS was the best tool to get numerical data and clearer results for the questionnaire. By using SPSS different results that involve both demographic profile and respondents' perceptions could be shown. The data was analysed according to the research questions. In this study, three tables were constructed according to three research questions with percentages (\%), mean (M) and standard deviation (SD) according to the questions in the administered questionnaires. The number of frequency $=\mathrm{n}$ and percentage $=\%$ in the three tables explained the responses for the questionnaires.

\section{RESULTS AND DISCUSSION}

\subsection{Section a-pre-service teachers' preferences}

Table 1 shows pre-service teachers' preferences in using games during language teaching. The descriptive statistics for 'Playing games enquires too much engagement time' during lesson revealed a $\mathrm{M}=3.67$ ( $\mathrm{SD}=.890)$ where a total of $39.4 \%$ pre-service teachers agreed to the statement. The descriptive statistics for 'Playing games stimulates curiosity in leaning something' revealed the highest mean with $\mathrm{M}=4.24(\mathrm{SD}=.502)$ showing a vast majority of pre-service teachers agreed. As for 'When games are played with group, this helps development of social skills' revealed a $\mathrm{M}=4.18$ ( $\mathrm{SD}=1.044$ ) with 48.5\% (Agree) and 42.4\% (Totally Agree) responses. The descriptive statistics for 'Games provide cooperative learning environment' revealed a $\mathrm{M}=3.85$ ( $\mathrm{SD}=1.034)$. The descriptive statistics for 'It is easy for me to use games in the classroom' indicated a $\mathrm{M}=3.55(\mathrm{SD}=1.063)$. 
Table 1. Pre-service teachers' preference

\begin{tabular}{|c|c|c|c|c|c|c|c|}
\hline \multirow[b]{2}{*}{ Question(s) } & \multicolumn{6}{|c|}{ Percentage (\%) } & \multirow[b]{2}{*}{$\begin{array}{c}\text { Std. } \\
\text { Deviation }\end{array}$} \\
\hline & $\begin{array}{c}\text { Totally } \\
\text { Disagree }\end{array}$ & Disagree & Neutral & Agree & $\begin{array}{c}\text { Totally } \\
\text { Agree }\end{array}$ & Mean & \\
\hline $\begin{array}{l}\text { 1. Playing games requires too much } \\
\text { engagement time }\end{array}$ & 0 & 9.1 & 33.3 & 39.4 & 18.2 & 3.67 & .890 \\
\hline $\begin{array}{l}\text { 2. Playing game stimulatws euriosty in } \\
\text { learning something }\end{array}$ & 0 & 0 & 3 & 69.7 & 27.3 & 4.24 & .502 \\
\hline $\begin{array}{l}\text { 3. When games are played with a group, } \\
\text { this helps development of social skills }\end{array}$ & 6.1 & 3 & 0 & 48.5 & 42.4 & 4.18 & 1.044 \\
\hline $\begin{array}{l}\text { 4. Games provide coorperative learning } \\
\text { environment }\end{array}$ & 3 & 6.1 & 24.2 & 36.4 & 30.3 & 3.85 & 1.034 \\
\hline $\begin{array}{l}\text { 5. It is easy for me to use games in the } \\
\text { classroom }\end{array}$ & 3 & 12.1 & 33.3 & 30.3 & 21.2 & 3.55 & 1.063 \\
\hline
\end{tabular}

\subsection{Section b-barriers in using gamified activities}

Table 2 shows barriers faced by pre-service teachers while using gamified activities in language teaching over the 16-week internship. The descriptive statistics for 'Students get side-tracked and do not focus on learning when games are used' indicated a $\mathrm{M}=3.76(\mathrm{SD}=.792)$ with the highest responses agreed $(42.4 \%)$ to the statement. The descriptive statistics for 'It is difficult to evaluate students' performance/learning from playing games' revealed a $\mathrm{M}=3.36(\mathrm{SD}=1.141)$. As for 'Lack of availability of games that match the teachers' subject area', the descriptive statistics indicated a $\mathrm{M}=3.79(\mathrm{SD}=.992)$ with the highest total of pre-service teachers agreed $(45.5 \%)$. The descriptive statistics for 'Some games are too complicated for students' revealed a $\mathrm{M}=3.88$ ( $\mathrm{SD}=.857)$. Based on descriptive statistics for 'Inadequate technology support' and 'Lack of supporting materials for how to best use the games for learning', revealed a $\mathrm{M}=4.09$ ( $\mathrm{SD}=.947)$ and $\mathrm{M}=4.00(\mathrm{SD}=.866)$ respectively. In addition, the descriptive statistics for 'Lack of teacher resources available for training' indicated a $\mathrm{M}=3.94(\mathrm{SD}=.998)$. As for 'There is limited or no available time to play games due to the need to meet all of the required curriculum standards', the descriptive statistics indicated a $\mathrm{M}=3.91$ ( $\mathrm{SD}=.914)$.

Table 2. Barriers in using gamified activities

\begin{tabular}{|c|c|c|c|c|c|c|c|}
\hline \multirow[b]{2}{*}{ Question(s) } & \multicolumn{4}{|c|}{ Percentage $(\%)$} & \multirow[b]{2}{*}{$\begin{array}{c}\text { Totally } \\
\text { Agree }\end{array}$} & \multirow[b]{2}{*}{ Mean } & \multirow[b]{2}{*}{$\begin{array}{c}\text { Std. } \\
\text { Deviation }\end{array}$} \\
\hline & $\begin{array}{c}\text { Totally } \\
\text { Disagree }\end{array}$ & Disagree & Neutral & Agree & & & \\
\hline $\begin{array}{l}\text { 1. Students get side-tracked and do } \\
\text { not focus on learning when } \\
\text { games are used }\end{array}$ & 0 & 3 & 36.4 & 42.4 & 18.2 & 3.76 & .792 \\
\hline $\begin{array}{l}\text { 2. It is difficult to evaluate } \\
\text { students' permormance/learning } \\
\text { from playing games }\end{array}$ & 6.1 & 18.2 & 24.2 & 36.4 & 15.2 & 3.36 & 1.141 \\
\hline $\begin{array}{l}\text { 3. Lack of availability of game that } \\
\text { match the teachers' subject area }\end{array}$ & 0 & 15.2 & 15.2 & 45.5 & 24.2 & 3.79 & .992 \\
\hline $\begin{array}{l}\text { 4. Some games are too } \\
\text { complicated for students }\end{array}$ & 0 & 9.1 & 15.2 & 54.5 & 21.2 & 3.88 & .857 \\
\hline 5. Inadequate technology support & 0 & 6.1 & 21.2 & 30.3 & 42.4 & 4.09 & .947 \\
\hline $\begin{array}{l}\text { 6. Lack of supporting materials for } \\
\text { how to best use the games for } \\
\text { learning }\end{array}$ & 0 & 6.1 & 18.2 & 45.5 & 30.3 & 4.00 & .866 \\
\hline $\begin{array}{l}\text { 7. Lack of teachers resources } \\
\text { available for training }\end{array}$ & 3 & 6.1 & 15.2 & 45.5 & 30.3 & 3.94 & .998 \\
\hline $\begin{array}{l}\text { 8. There is limited or no available } \\
\text { time to play game due to the } \\
\text { need to meet all of the required } \\
\text { curriculum standards }\end{array}$ & 0 & 6.1 & 27.3 & 36.4 & 30.3 & 3.91 & .914 \\
\hline
\end{tabular}

\subsection{Section c-pre-service teachers' perception on gamification}

Table 3 shows pre-service teachers' perception on the effectiveness of using gamification in language teaching. The descriptive statistics for 'Game-based learning contributed to the development of creative thinking skills revealed a $\mathrm{M}=4.09$ ( $\mathrm{SD}=.914)$. As for 'Game-based learning contributed to the development of critical thinking skills, the descriptive statistics revealed a $\mathrm{M}=3.91 \quad(\mathrm{SD}=1.042)$. The descriptive statistics for 'Game-based learning contributed to the development of problem-solving skills' indicated a $\mathrm{M}=3.85$ ( $\mathrm{SD}=.939)$. In addition, the descriptive statistics for 'Game-based learning decreased my anxiety level towards primary reading and writing lessons' stated a $\mathrm{M}=3.88(\mathrm{SD}=.992)$. The descriptive 
statistics for both 'I believe that I can use games I prepared effectively in my teaching life' and 'I believe that using games can lower learners' anxiety' revealed a $\mathrm{M}=3.82$ ( $\mathrm{SD}=.983$ ) and a $\mathrm{M}=3.76(\mathrm{SD}=1.001)$ respectively. Both questions received a total of $30.3 \%$ (Totally Agree) responses by pre-service teachers.

Table 3. Pre-service teachers' perception on gamification

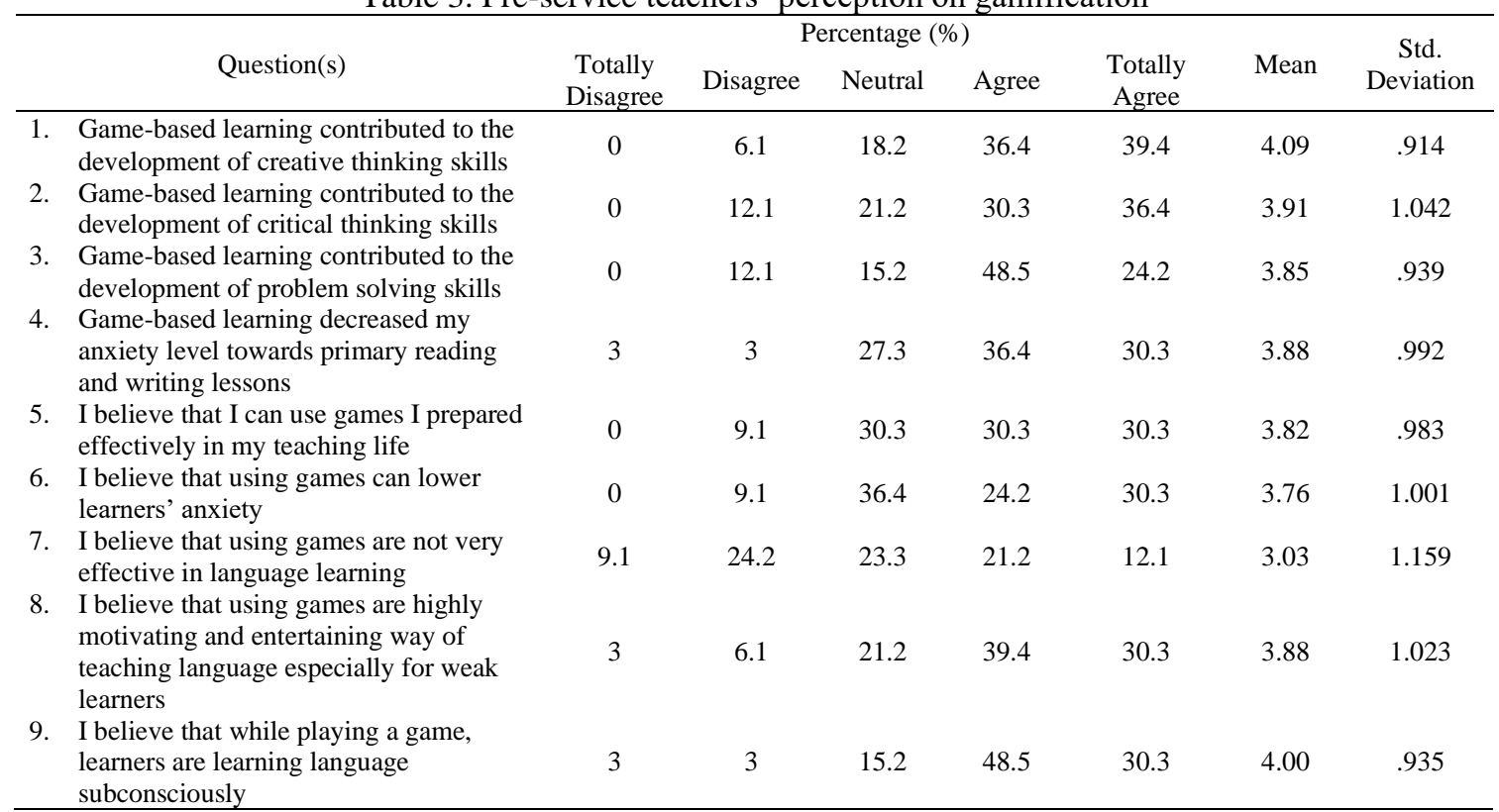

A relatively low $\mathrm{M}=3.03$ ( $\mathrm{SD}=1.159)$ in descriptive statistics for 'I believe that using games are not very effective in language learning' with a total of $9.1 \%$ respondents stated, 'Totally Disagree'. On the other hand, the descriptive statistics for 'I believe that using games are highly motivating and entertaining way of teaching language, especially for weak learners' indicated a $\mathrm{M}=3.88$ ( $\mathrm{SD}=1.023)$. As for 'I believe that while playing a game, learners are learning language subconsciously' revealed a $\mathrm{M}=4.00(\mathrm{SD}=.935)$ with the highest response from the respondents indicating 'Agree' with $48.5 \%$.

In correlation with the study, nearly more than half of the respondents agreed with the statements in the questionnaire. In brief, the pre-service teachers preferred using gamification in their teaching and agreed that game-based learning was able to create a suitable environment for their learners to learn. The result showed that incorporating games while teaching was able to lead to successful results as the learners did not feel the pressure of learning the subject and were able to motivate them to perform better. In contrast, a number of pre-service teachers agreed that they were not equipped with enough knowledge or media literacy to obtain the suitable type of content which was needed for their lessons [24].

As for barriers faced by pre-service teachers in integrating gamified activities in classroom teaching, most of respondents agreed that they were able to relate and agreed to the existing barriers suggested in the questionnaire provided. These barriers could be explained and supported by the six categories of barriers involving resources, knowledge and skills, institutions, attitudes and beliefs, assessment, and subject culture [25]. The respondents mostly agreed to the barriers of lack of adequate technology and resources to support the use of technology in games integration. This could be concordant by the research conducted by Sánchez-Mena \& Martí-Parreño [26].

The findings showed that games developed learners' creative, critical as well as problem solving skills. The educational benefits of games, which explained that games are stimulating, motivating as well as entertaining [27]. The results showed teachers enjoyed the use of games in the classroom but they were concerned with their own abilities in conducting the lesson [28]. In this study however, 30.3\% of the respondents totally agreed that using games was able to lower pre-service teachers' anxiety while teaching. Hence, consistent used of games in the classroom would help learners to be familiar with the teaching style and helped them enhance their skills [1]. These results also showed that pre-service teachers totally agreed with the fact that game-based learning were able to promote creative, critical and problem-solving skills [29].

Gamification is taking the element of fun and creativity into classroom teaching. It is not an unusual fact that the motivation of playing games varies between the gender or age group of learners [30] but it should not be forgotten of how effective it is in teaching lessons. It is not uncommon to use gamification in 
classroom teaching, and due to the era of 21 st century teaching, teachers should be able to create a fun and creative learning environment for learners to learn. In this study, the topic of gamification was explored and the results was to investigate the views of pre-service teachers on their preference in using gamification, the barriers of gamification and the effectiveness of gamification in classroom teaching. As the study looked into the perceptions of pre-service teachers, it was able to identify some of the problems faced and awareness could be highlighted to schools in upgrading their facilities in order to create a more conducive environment for language teaching.

\section{CONCLUSION}

Gamification in education plays an important role in improving learners' creative, critical and problem-solving skills. The integration of interesting and engaging activities sparks learners' interest in language learning subconsciously. In correlation with the findings, participants agreed that the use of gamification activities could further learners' anxiety and the use of games that are highly motivating and entertaining could attract learners with weak proficiency into participating in classroom learning. It was, however, important for pre-service teachers to be able to look for suitable materials and gamified activities to match the subject area for teaching and learning in the classroom. Without technology support and teacher resources, the success in classroom education will be hampered. Hence, a successful learning environment for learners requires the support from the school authority to continuously provide training its teachers.

\section{ACKNOWLEDGEMENTS}

We would like to thank the Malaysian Ministry of Higher Education for funding this study under Fundamental Research Grant Scheme (FRGS Nos. FRGS/1/2019/SSI09/UNISEL/03/3). This work was supported by Universiti Selangor (UNISEL).

\section{REFERENCES}

[1] A. F. Chow, K. C. Woodford, and J. Maes, "Deal or No Deal: Using Games to Improve Student Learning, Retention and Decision-Making," International Journal of Mathematical Education in Science and Technology, vol. 42, no. 2, pp. 259-264, 2011

[2] R. Ibrahim, R. C. M. Yusoff, H. Mohamed-Omar, and A. Jaafar, "Students Perceptions of Using Educational Games to Learn Introductory Programming," Computer and Information Science, vol. 4, no. 1, pp. 201-216, 2011.

[3] E. Koh, Y. G. Kin, B. Wadhwa, and J. Lim, "Teacher Perceptions of Games in Singapore Schools," Simulation \& Gaming, vol. 43, no. 1, pp. 51-66, 2012.

[4] S. Ghavifekr, T. Kunjappan, L. Ramasamy, and A. Anthony, "Teaching and Learning with ICT Tools: Issues and Challenges from Teachers' Perceptions," Malaysian Online Journal of Educational Technology, vol. 4, no. 2, pp. 38-57, 2016.

[5] Sudiran, "Students' Perception Towards the Use of Internet as Learning Media to Promote Reading Comprehension Skill," Sino-US English Teaching, vol. 12, no. 9, pp. 684-692, 2015.

[6] M. F. Buck, "Gamification of Learning and Teaching in Schools-A Critical Stance," International Journal of Media, Technology and Lifelong Learning, vol. 13, no. 1, pp. 35-54, 2017.

[7] V. Giang, "Gamification" Techniques Increase Your Employees' Ability to Learn by 40\%" From Business Insider, 2013. [Online]. Available: http://whttp://www.businessinsider.com/gamification-techniques-increase-youremployeesability-to-learn-by-40-2013-9

[8] D. Dicheva, C. Dichev, G. Agre, and G. Angelova, "Gamification in Education: A Systematic Mapping Study," Educational Technology \& Society, vol. 18, no. 3, pp. 75-88, 2015.

[9] I. Alomari, H. Al-Samarraie, and R. Yousef, "The Role of Gamification Techniques in Promoting Student Learning: A Review and Synthesis," Journal of Information Technology Education: Research, vol. 18, pp. 395-417, 2019.

[10] C.-H. Su and C.-H. Cheng, "A mobile game-based insect learning system for improving the learning achievements," Procedia - Social and Behavioral Sciences, vol. 103, pp. 42-50, Nov 2013.

[11] W.-H. Wu, Y.-C. J. Wu, C.-Y. Chen, H.-Y. Kao, and C.-H. Lin, "Review of Trends from Mobile Learning Studies: A Meta-Analysis," Computers \& Education, vol. 59, no. 2, pp. 817-827, 2012.

[12] J. L. Plass, B. D. Homer, and C. K. Kinzer, "Foundations of Game-Based Learning," Educational Psychologist, vol. 50, no. 4, pp. 258-283, 2015

[13] A. Hirumi, B. Appelman, L. Rieber, and R. Van Eck, "Preparing Instructional Designers for Game-Based Learning: Part 1," Techtrends: Linking Research and Practice to Improve Learning, vol. 54, no. 3, pp. 27-37, 2010.

[14] S. Kim, K. Song, B. Lockee, and J. Burton, "What is Gamification in Learning and Education?" In Gamification in Learning and Education: Enjoy Learning Like Gaming, pp. 25-38, 2018.

[15] J. Figueroa, "Using Gamification to Enhance Second Language Learning," Digital Education Review, vol. 21, pp. 32-54, 2015. 
[16] O. Zuckerman, and A. Gal-Oz, "Deconstructing Gamification: Evaluating the Effectiveness of Continuous Measurement, Virtual Rewards, and Social Comparison for Promoting Physical Activity," Personal and Ubiquitous Computing, vol. 18, no. 7, pp. 1705-1719, 2014.

[17] S. Nicholson, "A Recipe for Meaningful Gamification," in Reiners T., Wood L. (eds), Gamification in Education and Business. Switzerland: Springer, pp. 1-20, 2015.

[18] S. P. Walz and S. Deterding, "Why Gamification Is Bullshit," in Gameful World: Approaches, Issues, Applications, London, UK: The MIT Press, pp. 65-79, 2015.

[19] A. Yolageldili, and A. Arikan, "Effectiveness of Using Games in Teaching Grammar to Young Learners," Elementary Education Online, vol. 10, no. 1, pp. 219-229, 2011

[20] Y. F. Lay, S. L. Chang, Hamdan Adnan, and S. F. Fong, "Gamification at Universiti Malaysia Sabah: A Case Study of Enhancing English among Undergraduate Students," Jurnal Pemikir Pendidikan, vol. 7, pp. 19-43, 2016.

[21] E. D. Mekler, F. Brühlmann, A. N. Tuch, and K. Opwis, "Towards Understanding the Effects of Individual Gamification Elements on Intrinsic Motivation and Performance," Computers in Human Behavior, vol. 71, pp. 525-534, Jun 2017.

[22] B. L. Butler, and C. A. Bodnar, "Establishing the Impact That Gamified Homework Portals Can Have on Students' Academic Motivation," Proceedings of the 2017 American Society for Engineering Education (ASEE) Annual Conference \& Exposition, 2017.

[23] J. W. Creswell, Research Design: Qualitative, Quantitative and Mixed Methods Approaches (4th ed). Thousand Oaks, CA: Sage, 2014.

[24] C. Singhavi, and P. Basargekar, "Barriers Perceived by Teachers for use of Information and Communication Technology (ICT) in the Classroom in Maharashtra, India," International Journal of Education and Development using Information and Communication Technology (IJEDICT), vol. 15, no. 2, pp. 62-78, 2019.

[25] M. S. Khalid, K. Islam, and T. Nyvang, "Integrated Resources and Training Facilitation: A Strategic Priority when Promoting ICT in Developing Countries," Contemporary Educational Technology, vol. 4, no. 4, pp. 263-280, 2013.

[26] A. Sánchez-Mena, and J. Martí-Parreño, "Drivers and Barriers to Adopting Gamification: Teachers' Perspectives," The Electronic Journal of e-Learning, vol. 15, no. 5, pp. 434-443, 2017.

[27] V. S. Zirawaga, A. I. Olusanya, and T. Maduku, "Gaming in Education: Using Games as a Support Tool to Teach History," Journal of Education and Practice, vol. 8, no. 15, pp. 55-64, 2017.

[28] A. Alkan, and H. Mertol, "Teacher Candidates' State of Using Digital Educational Games," International Journal of Evaluation Research in Education (IJERE), vol. 8, no. 2, pp. 344-350, 2019.

[29] R. Mathew, S. I. Malik, and R. M. Tawafak, "Teaching problem solving skills using an educational game in a computer programming course," Informatics in Education, vol. 18, no. 2, pp. 359-373, 2019.

[30] D. Vlachopoulos, and A. Makr, "The Effect of Games and Simulations on Higher Education: A Systematic Literature Review," International Journal of Educational Technology in Higher Education, vol. 14, no. 22, pp. 1-33, 2017. 